\title{
Peran Forum Pinilih Sedayu dalam Pemberdayaan Ekonomi Penyandang Disabilitas
}

\author{
Arni Surwantí1, Retno Widowati Purnama Asri 2 \\ Magister Manajemen, ProgramPascasarjana, Universitas Muhammadiyah Yogyakarta, J. Brawijaya Tamantirto Yogyakarta \\ Email:arni_surwanti@umy.ac.id \\ DOI: $10.18196 / p p m .32 .214$
}

\begin{abstract}
Abstrak
Penyandang disabilitas selama ini mengalami kesulitan untuk mendapatkan pekerjaan. Hal yang sama juga ada pada penyandang disabilitas yang ada di Desa Argomulyo Sedayu, Bantul Yogyakarta. Program Kemitraan Masyarakat diharapkan dapat menyelesaikan permasalahan tersebut dengan meningkatan motivasi penyandang disabilitas anggota kelompok "PINILIH" untuk bermasyarakat dan bekerja melalui wirausaha mandiri; meningkatan ketrampilan penyandang disabilitas anggota kelompok "PINILIH" untuk dalam memproduksi olahan makanan kering; meningkatan pemahaman kewirausahaan bagi penyandang disabilitas anggota kelompok "PINILIH"; Pemberian pengetahuan pendampingan bagi pengurus kelompok "PINILIH" dalam memastikan wirausaha mandiri penyandang disabilitas dapat berjalan baik.
\end{abstract}

Kata Kunci: ; ketrampilan, kewirausahaan, penyandang disabilitas, pendampingan

\section{Pendahuluan}

Perkiraan jumlah penduduk usia kerja penyandang disabilitas di Indonesia adalah sekitar 19,3 juta. Partisipasi angkatan kerja penyandang disabilitas ringan dan berat adalah 56,72 persen untuk penyandang disabilitas ringan dan 20,27 persen untuk penyandang disabilitas berat [8]. Persentase ini jauh lebih rendah dibandingkan dengan tingkat partisipasi angkatan kerja non-penyandang disabilitas, yaitu 70,40 persen. Kesulitan Penyandang Disabilitas untuk memasuki angkatan kerja mungkin disebabkan oleh beberapa diskriminasi yang dihadapi oleh penyandang disabilitas, yaitu diskriminasi kelembagaan, diskriminasi lingkungan fisik dan diskriminasi sosial.

Sejumlah penyandang disabilitas memberi kesaksian bahwa sikap diskriminatif dari pengusaha terlihat jelas pada saat perekrutan. Di sisi lain, beberapa pengusaha menyatakan ragu mempekerjakan penyandang disabilitas karena beberapa alasan, termasuk kurangnya kesadaran tentang disabilitas dan kekhawatiran akan akomodasi, masalah terkait biaya dan kewajiban hukum. Tidak dapat disangkal bahwa bagi sebagian orang berpendapat bahwa disabilitas bisa mengganggu kinerja mereka dalam memangku sebuah pekerjaan dan perusahaan dalam kadar tertentu harus memberikan kebutuhan khusus untuk mereka. Namun, banyak penyandang disabilitas dapat berkinerja baik tidak bisa memperoleh upah setara dengan beberapa alasan. Diskriminasi terhadap penyandang disabilitas tidak hanya menghambat kesempatan mereka mencari pekerjaan, tapi juga menyebabkan kesenjangan upah bagi penyandang disabilitas yang sudah bekerja.

Dalam konteks di daerah ada berbagai factor yang juga hampir sama dengan yang terjadi di berbagai Negara dan daerah yang menyebabkan penyandang disabilitas sulit mendapatkan pekerjaan. Beberapa factor tersebut adalah Banyak penyandang disabilitas memiliki pendidikan dan ketrampilan masih rendah. Berdasarkan Laporan Pemetaan Penyandang Disabilitas di Pasar Tenaga kerja Indonesia, ILO [9], proporsi penyandang disabilitas yang tidak lulus sekolah dasar $46 \%$, sedangkan yang lulus perguruan tinggi hanya 5\%; Pemerintah, perusahaan atau instansi pemberi kerja tidak memahami potensi tenaga kerja disabilitas; Pemerintah, perusahaan atau instansi pemberi kerja tidak bisa menemukan sumberdaya manusia disabilitas; Pemerintah, perusahaan atau instansi pencari kerja belum memahami tentang pekerjaan yang bisa dikerjakan oleh penyandang disabilitas; Pemerintah, perusahaan atau instansi pencari kerja belum memahami tentang kebijakan yang melindungi hak ketenagakerjaan disabilitas; Informasi 
kesempatan kerja tidak bisa diakses oleh penyandang disabilitas; Belum tersedianya akomodasi yang layak di tempat kerja, sehingga menjadikan penyandang disabilitas dipandang tidak bisa melakukan pekerjaan;Perbedaan perlakuan pengupahan bagi tenaga kerja disabilitas.

Berbagai persoalan ini dapat teratasi apabila pemerintah daerah menyediakan adanya lembaga (unit) yang menfasilitasi tenaga kerja disabilitas untuk mendapatkan pekerjaan dan memastikan hak-hak mereka terpenuhi sebagai pekerja disabilitas. Hal ini didasarkan pertimbangan masih sedikit sekali pemerintah daerah yang memiliki unit layanan disabilitas.

Walaupun tanggungjawab utama memastikan penyandang disabilitas mendapatkan pekerjaan ada di pemerintah, namun juga tidak bisa diabaikan peran masyarakat. Peran masyarakat juga diperlukan untuk memfasilitasi penyandang disabilitas untuk mendapatkan pekerjaan formal ataupun menfasilitasi perluasan kesempatan kerja melalui wirausaha mandiri

Program Kemitraan Masyarakat ini akan dilaksanakan di, Kecamatan Sedayu, Kabupaten Bantul Propinsi Daerah Istimewa Yogyakarta [1]. Kecamatan Sedayu mempunyai luas 34,36 km2. Sebelumnya bernama Kapanewon PEDES. Berdasarkan Peraturan Pemerintah Daerah Istimewa Yogyakarta nomor 9 tahun 1951, tanggal 20 Juni 1951, berganti nama menjadi Kapanewon SEDAYU. Kecamatan Sedayu berada di wilayah Kabupaten Bantul yang berbatasan dengan Kabupaten Sleman dan Kabupaten Kulon Progo. Kecamatann Sedayu berada di sebelah Barat Laut dari Ibukota Kabupaten Bantul. Wilayah administrasi Kecamatan Sedayu meliputi 4 desa : Desa Argodadi, Desa Argorejo, Desa Argosari, Desa Argomulyo.

Sementara itu di Kecamatan Sedayu memiliki kelompok masyarakat "PINILIH" yang beranggotakan penyandang disabilitas dan keluarga. Kelompok ini telah melakukan pendataan dan melakukan referal apabila ada anggotanya yang memiliki kebutuhan layanan dari pemerintah. Namun kelompok ini belum memiliki kemampuan untuk memberikan pemberdayaan ekonomi bagi penyandang disabilitas dan keluarganya. Pada saat ini, penyandang disabilitas di Kecamatan Sedayu sebagaimana juga yang terjadi pada di desa lain di Propinsi Daerah Istimewa Yogyakarta masih menghadapi persoalan yang berkenaan dengan kesejahteraan penyandang disabilitas karena tidak bisa mendapatkan pekerjaan. Karakteristik penyandang disabilitas diKecamatan Sedayu, sebagaimana rata-rata kondisi penyandang disabilitas di Kabupaten Bantul, antara lain adalah:

1. Masih menghadapi masalah psikhologis; seperti tidak berani keluar rumah karena malu, tidak percaya diri, ketakutan.

2. Produktifitas sumberdaya manusia penyandang disabilitas relatif rendah karena belum banyak mendapatkan kesempatan pelatihan kerja;

3. Kemampuan untuk mendirikan usaha mandiri rendah, karena ketiadaan ketrampilan, kesulitan untuk mendapatkan akses permodalan; kemampuan melakukan pemasaran usaha masih rendah.

4. Tidak ada pihak yang memberikan pendampingan dalam menjalani wirausaha mandiri

\section{Metode Pelaksanaan}

Kegiatan Kemitraan Masyarakat ini diharapkan dapat meningkatkan kesejahteraan kelompok sasaran adalah penyandang disabilitas diKecamatan Sedayu. Guna tercapainya output yag diharapkan yaitu berupa peningkatan kesejahteraan penyandang disabilitas dilakukan dengan adanya peran kelompok rehabilitasi berbasis masyarakat yang ada di Desa Argomulyo.

Program pengabdian masyarakat melalui Program Kemitraan Masyarakat ini diharapkan dapat berperan dalam:

1. Peningkatan motivasi penyandang disabilitas anggota kelompok "PINILIH" untuk bermasyarakat dan bekerja melalui wirausaha mandiri..

2. Peningkatan ketrampilan penyandang disabilitas anggota kelompok "PINILIH" untuk dalam memproduksi olahan makanan kering. 
3. Peningkatan pemahaman kewirausahaan bagi penyandang disabilitas anggota kelompok "PINILIH"

4. Pemberian pengetahuan pendampingan bagi pengurus kelompok "PINILIH" dalam memastikan wirausaha mandiri penyandang disabilitas dapat berjalan baik.

Output yang diharapkan adalah:

1. Adanya peningkatan motivasi penyandang disabilitas anggota kelompok "PINILIH" untuk bermasyarakat dan berusaha.

2. Adanya peningkatan ketrampilan penyandang disabilitas dalam bidang olahan makanan kering.

3. Adanya peningkatan pemahaman kewirausahaan bagi penyandang disabilitas anggota kelompok "PINILIH".

4. Adanya pengetahuan pendampingan bagi pengurus kelompok "PINILIH" dalam memastikan wirausaha mandiri penyandang disabilitas dapat berjalan baik.

Sosialisasi dan komunikasi dilakukan pada penyandang disabilitas dan keluarga dilakukan sebelum kegiatan dilaksanakan untuk mendapatkan dukungan.

\section{Hasil dan Pembahasan}

Dalam bidang ketenagakerjaan berdasarkan Konvensi UN-CRPD [4], UU No 8 tahun 2016[5], dan PERDA Propinsi Daerah Istimewa Yogyakarta No 4 Tahun 2012 [6], dan Perda Kabupaten Bantul No 11 tahun 2015 [7] tentang Perlindungan dan Pemenuhan Hak-hak Penyandang Disabilitas mengamanatkan bahwa Setiap Penyandang Disabilitas mempunyai hak dan kesempatan yang sama untuk mendapatkan pekerjaan dan/atau melakukan pekerjaan yang layak. Pemerintah berkewajiban memberikan fasilitasi agar penyandang disabilitas mendapatkan kesempatan untuk mendapatkan pekerjaan. Pemerintah Daerah dan Pemerintah Kabupaten/Kota perlu juga melakukan perluasan kesempatan kerja bagi Penyandang Disabilitas dalam bentuk usaha mandiri yang produktif dan berkelanjutan, dengan demikian kesempatan kerja penyandang disabilitas dapat dilakukan melalui intrapreneur yaitu dimana penyandang disabilitas dapat menjadi pekerja atau mendirikan usaha mandiri. Selama ini penyandang disabilitas mengalami kesulitan untuk bekerja di sektor formal, oleh karena itu pilihan menjalankan wirausaha mandiri merupakan pilihan yang memungkinkan bagi penyandang disabilitas untuk mendapatkan pekerjaan [6]. Sementara itu pada sisi lain untuk menjadi wirausaha diperlukan motivasi yang tinggi, memiliki ketrampilan, dan pengetahuan kewirausahaan. Oleh Karen itu solusi untuk memberikan perluasan kesempatan kerja bagi penyandang disabilitas adalah melalui tiga pilar yaitu pelatihan motivasi, pelatihan 


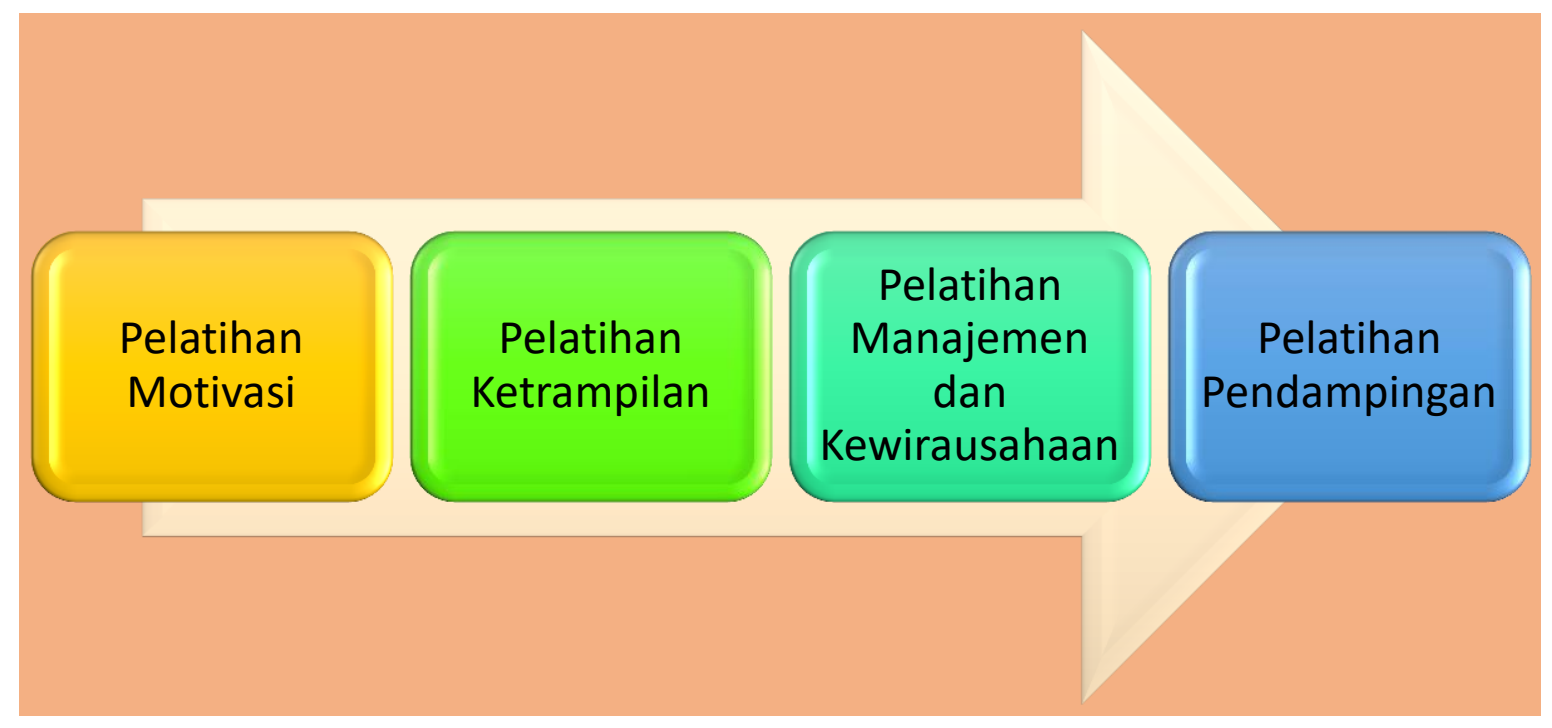

Gambar1. Gambar Program Dan Kegiatan Yang Dilaksanakan

ketrampilan, pelatihan kewirausahaan dan pelatihan untuk memberikan pendampingan bagi pengurus kelompok "PINILIH".

Program Kemitraan Masyarakat ini dapat dilaksanakan dengan gambaran program dan kegiatan adalah melakukan pemberdayaan ekonomi pada penyandang disabilitas dan keluarganya Kegiatan ini digunakan untuk mempersiapkan penyandang disabilitas dan keluarganya bisa melakukan wirausaha mandiri dalam memproduksi makanan kering, seperti keripik tempe, keripik bayam, rempeyek kacang, keripik belut. Metode pelaksanaan dilakukan melalui tahapan-tahapan berikut: Tahapan yang dilaksanakan adalah :

\section{Pelatihan Motivasi Pada Penyandang Disabilitas.}

Pada kegiatan ini peserta diberikan pengetahuan bagaimana penyandang disabilitas perlu berperan dan beraktivitas sebagaimana yang lain. Sebagaimana rata-rata kondisi penyandang disabilitas yang tidak mengenyam pendidikan formal mereka masih manghadapi masalah social dan masalah psikhologis. Masyarakat masih banyak memandang penyandang disabilitas adalah masyarakat yang tidak memiliki kompetensi apapun, stigma negative masih melekat pada penyandang disabilitas. Kondisi ini semakin memperparah kondisi psikhologis penyandang disabilitas yang masih malu, takut untuk bertemu banyak orang, tidak percaya diri. Pelatihan motivasi dimaksudkan untuk untuk memberikan kepercayaan diri dan menjaga agar motivasi penyandang disabilitas untuk bias berwirausaha meningkat. Pelatihan ini memberikan pemahaman bahwa penyandang disabilitas pun harus aktif berperan dalam masyarakat, dan perlu bekerja untuk meningkatkan kesejahteraan mereka, sehingga tidak bergantung pada orang lain. Kondisi ini yang juga pelan-pelan akan merubah stigma negatip dari masyarakat pada penyandang disabilitas. Keberhasilan kegiatan pelatihan ketrampilan dan pelatihan kewirausahaan sangat ditentukan dari adanya motivasi untuk belajar dan bekerja dari penyandang disabilitas.Pelatihan motivasi diberikan dengan memberikan contoh-contoh penyandang disabilitas yang telah berhasil. Pada kegiatan ini baru bias memberikan pemberdayaan pada 25 orang dari 320 orang penyadang disabilitas yang ada di Kecamatan Sedayu. Gambaran karakteristik penyandang disabilitas di kecamatan Sedayu adalah sebagai berikut: 


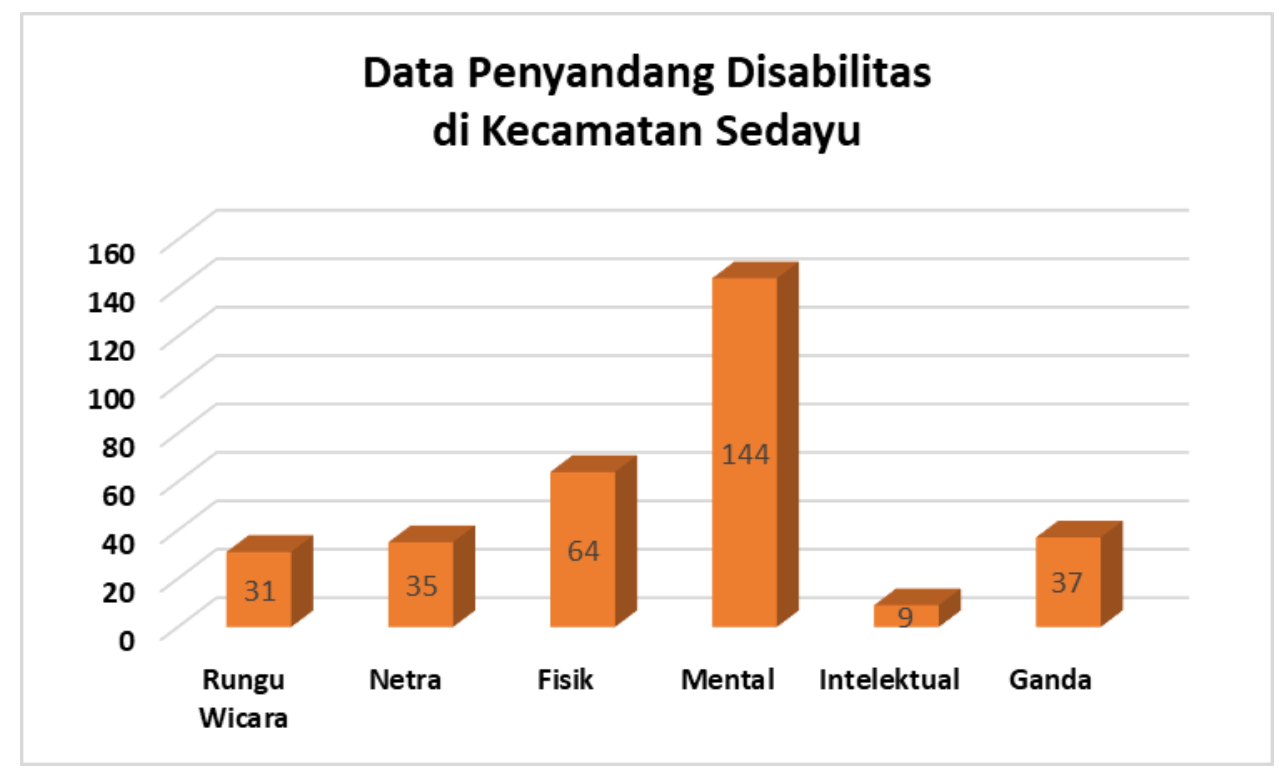

Gambar 2 Data Karakteristik Penyandang Disabilitas di Sedayu

Jumlah penyandang disabilitas di Kecamatan Sedayu ada 320 orang, dengan jumlah terbesar adalah dari disabilitas mental.

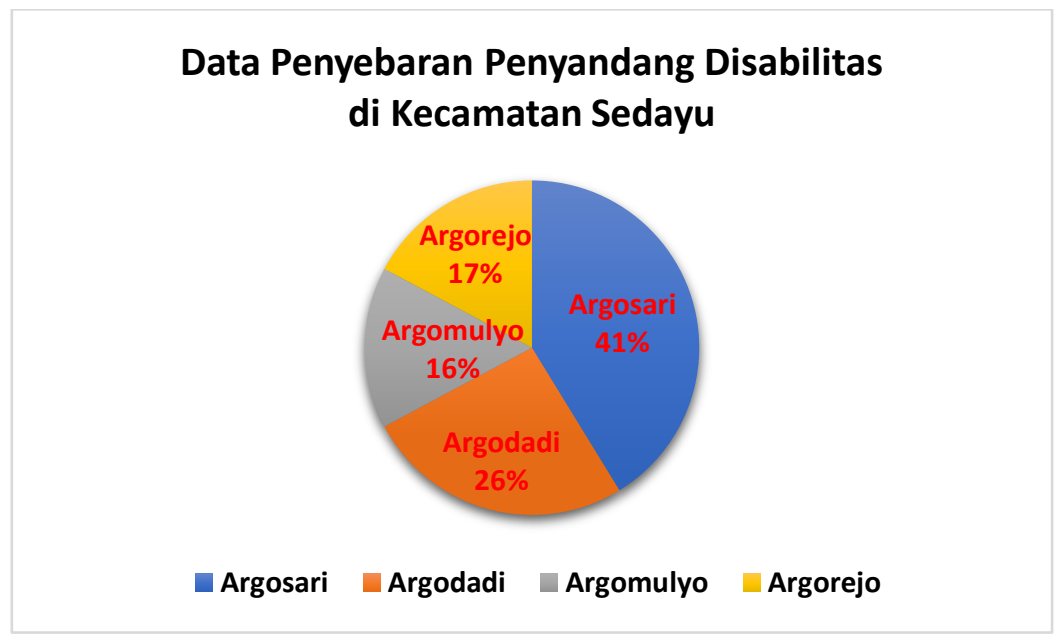

Gambar 3. Data Penyebaran Penyandang Disabilitas di Kecamatan Sedayu

Dan apabila dilihat penyebaranya pada 4 (empat) Desa, Jumlah penyandang disabilitas terbanyak ada di Desa Argosari.

\section{Pelatihan Ketrampilan Pada Bidang Makanan Kering, Seperti Keripik Tempe, Keripik Bayam, Rempeyek Kacang, Keripik Belut.}

Pelatihan ketrampilan merupakan salah satu cara untuk melakukan pemberdayaan ekonomi penyandang disabilitas. Selain bias digunakan dasar untuk mencari pekerjaan formal dengan pelatihan bias juga memperluas kesempatan kerja melalui berwirausaha [6]. Pelatihan ketrampilan pembuatan makanan kering ini diikuti oleh anggota kelompok "PINILIH" yang berada di kecamatan sedayu. Peserta berasal dari perwakilan beberapa desa yang ada di Kecamatan Sedayu. dipilih mewakili dari 4 (empat) desa yang ada di Kecamatan Sedayu. Perwakilan ini diharapkan akan bias menularkan ketrampilannya pada penyandang disabilitas di Desa masing-masing. Ketrampilan ini juga mempertimbangkan tidak membutuhkan dana yang besar untuk memulai usaha ini, dan dengan menggunakan bahan yang mudah ditemukan di wilayah setempat. Pelatihan dipandu langsung oleh pengusaha yang telah berpengalaman dalam usaha pembuatan makanan kering, dengan harapan produk yang dihasilkan dapat dengan 
kualitas yang baik dan sesuai dengan standard pasar, Pelatihan ketrampilan yang diberikan meliputi pelatihan pembuatan produk makanan kering sampai dengan cara pengemasan dan pemberian label pada kemasan produk. Gambaran pelaksanaan pelatihan ketrampilan:
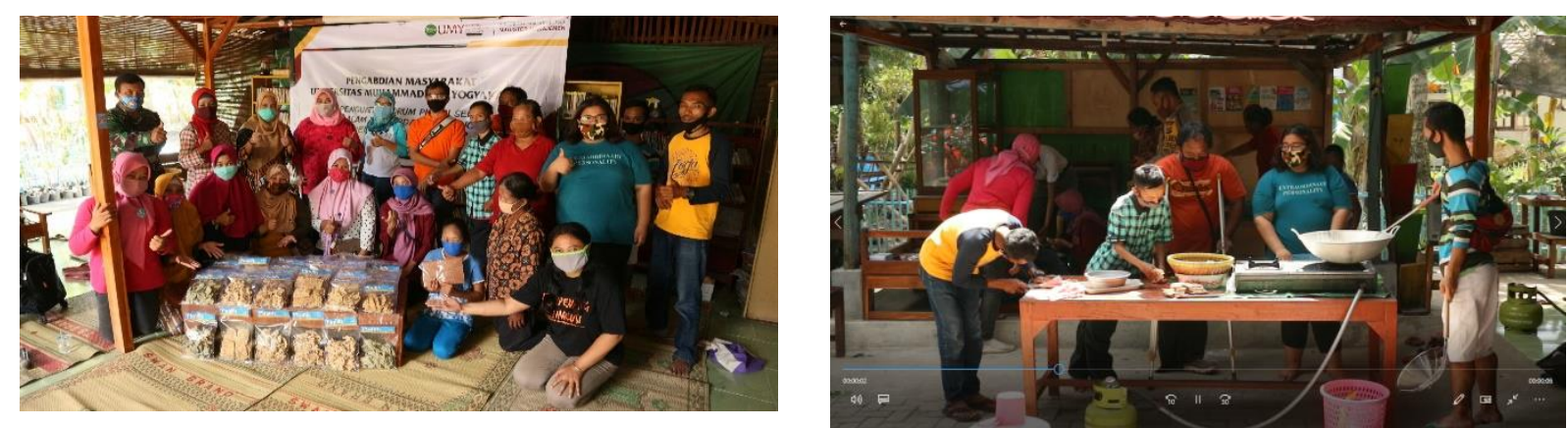

Gambar 4. Pelaksanaan Pelatihan Ketrampilan Pembuatan Makanan Keripik

\section{Pelatihan Manajemen Dan Kewirausahaan}

Pelatihan manajemen dan kewirausahaan dilaksanakan agar penyandang disabilitas dan keluarganya yang akan mendirikan wirausaha mandiri memiliki pemahaman tentang pengelolaan usaha baik itu bagaimana memproduksi, memasarkan.
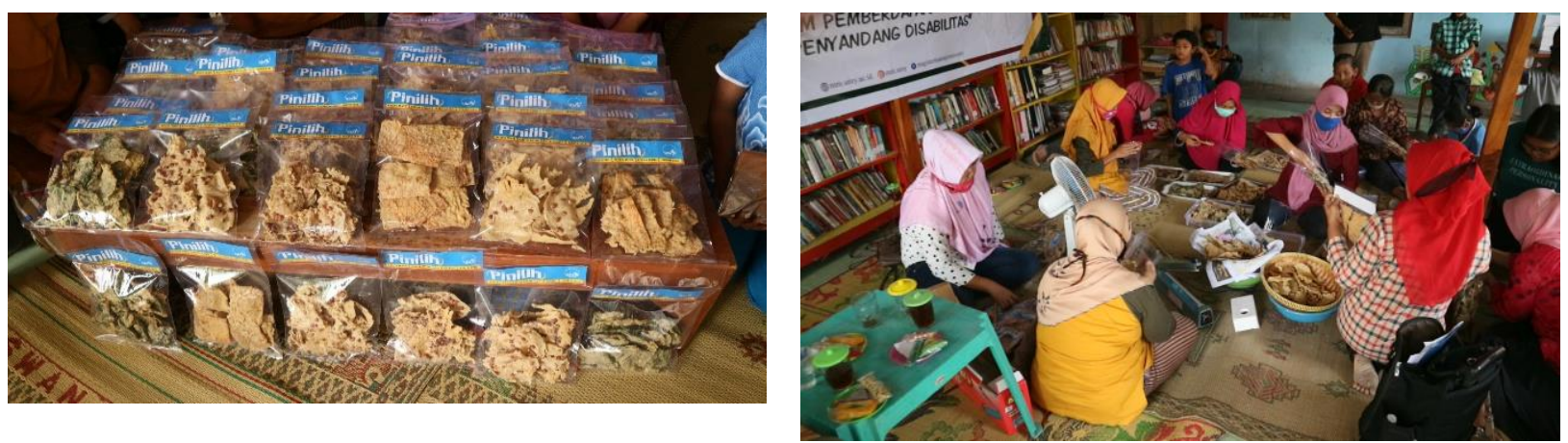

Gambar 5. Pelatihan Pengemasan

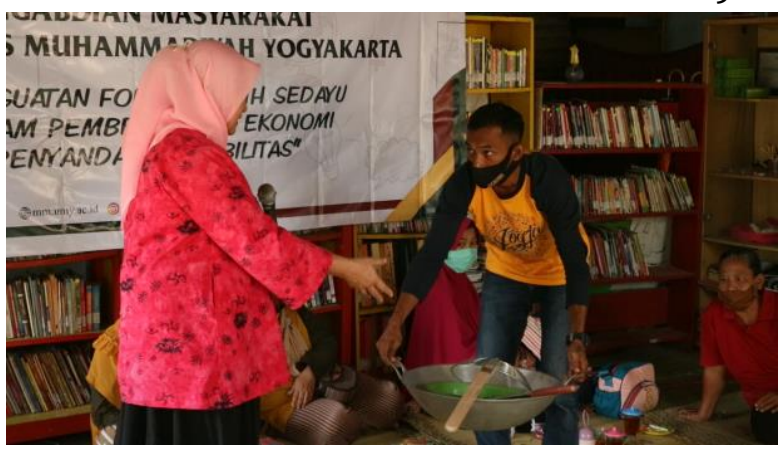

Gambar 6 Pemberian peralatan Kerja

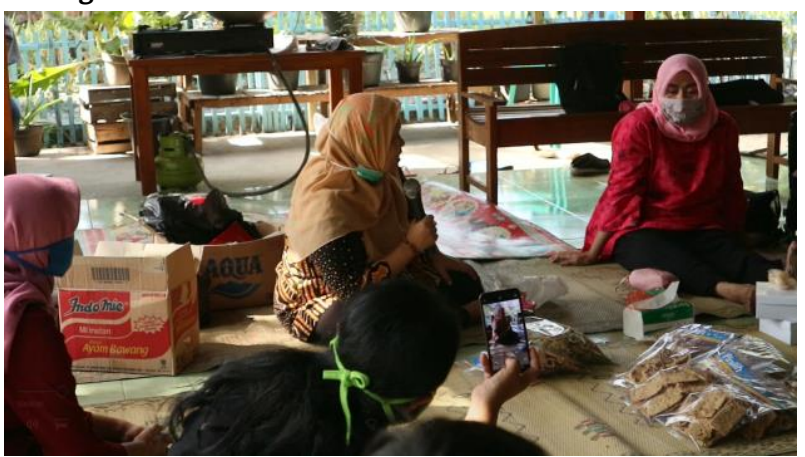

Gambar 7. Pelatihan Kewirausahaan

Pelatihan kewirausahaan diberikan untuk membekali peserta bagaimana menjadi seorang wirausaha. Peserta diberikan gambaran untuk menjadi wirausahawan diberikan pondasi ketrampilan dan mental yang memadai. Guna menjadi wirausaha masalah mental harus dibangun untuk mengelola kesuksesan, mengantisipasi kegagalan dan memotivasi untuk bekerja keras dan sungguh-sungun. Kewirausahaan juda memberikan ketrampilan bagaimana melihat peluang, mengelola resiko dan membangun usaha untuk bias mencapai hasil yang baik. Pada kegiatan ini juga disinggung tentang bagaimana mengelola usaha diperlukan pemahaman bagaimana pengelolaan pemasaran, kerjasama sumberdaya manusia yang ada, menjamin produk yang berkualitas, dan pengelolaan keuangannya. 


\section{Pelatihan pada pengurus PINILIH untuk bisa memberikan pendampingan bagi wirausaha yang dikelola oleh penyandang disabilitas.}

Guna menjadi keberlanjutan program, untuk kegiatan pada waktu yang akan datang diharapkan dapat menggunakan dana anggaran desa, dana anggaran kecamatan dan dana anggaran kabupaten, atau dana masyarakat untuk terus menerus melaksanakan program dan kegiatan kelompok PINILIH guna menjamin penyandang disabilitas mendapatkan layanan sesuai dengan kebutuhannya. Berdasarkan hasil kegiatan ini pengusul dapat memfasilitasi jejaring dengan Lazismu Sedayu yang memiliki komitmen untuk melakukan pemberdayaan secara inklusi. Langkah awal dari komiten itu yaitu dengan memberikan pemberdayaan penanaman Jahe merah.
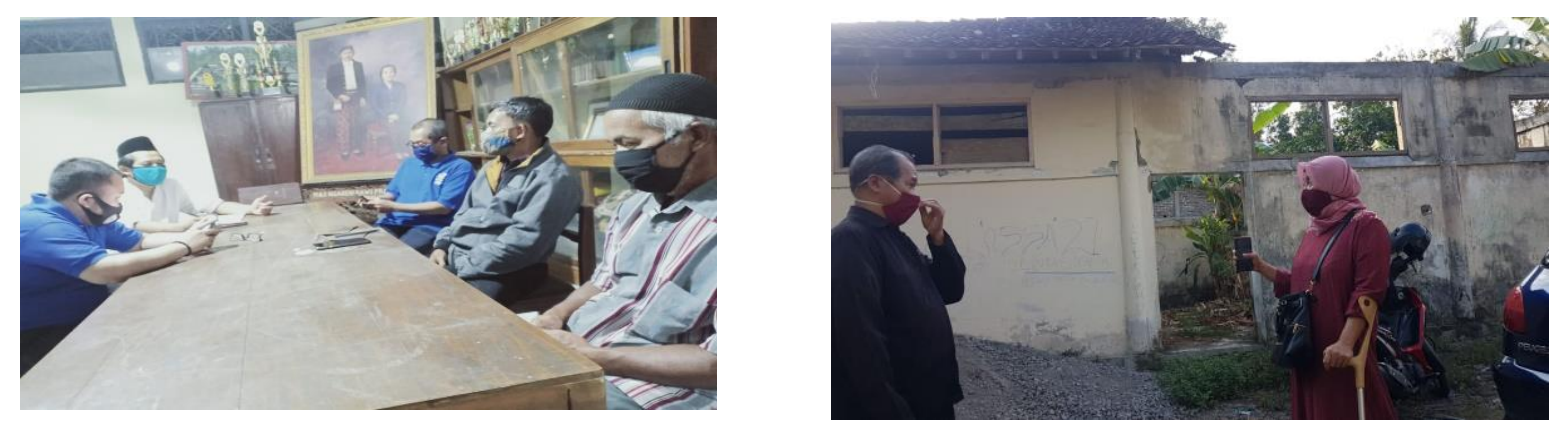

Gambar 9 Diskusi dengan Lazismu Sedayu dan Masyarakat untuk mendukung pemberdayaan secara inklusi di Kecamatan Sedayu

\section{Simpulan}

Program Kemitraan Masyarakat menjadi salah satu media diharapkan dapat menyelesaikan permasalahan ketenagakerjaan penyandang disabilitas. Kegiatan yang dilakukan melalui peningkatan motivasi penyandang disabilitas anggota kelompok "PINILIH" untuk bermasyarakat dan bekerja melalui wirausaha mandiri; meningkatan ketrampilan penyandang disabilitas anggota kelompok "PINILIH" untuk dalam memproduksi makanan olahan kering; meningkatan pemahaman kewirausahaan bagi penyandang disabilitas anggota kelompok "PINILIH"; Pemberian pengetahuan pendampingan bagi pengurus kelompok "PINILIH" dengan memfasilitasi jejaring dengan berbagai pihak mendukung terwujudnya kemandirian secara ekonomi penyandang disabilitas.

\section{Ucapan Terima Kasih}

Pada Program Kemitraan Masyarakat ini didukung oleh Universitas Muhammadiyah Yogyakarta yang telah memberikan dukungan materiil dan non materiil. Ucapan terima kasih terutama kepada pemberi dana yaitu Universitas Muhammadiyah Yogyakarta berdasarkan nomor kontrak 031/PEN-LP3M/I/2020. Ucapan terima kasih juga diberikan kepada Ibu Tri Suhartini yang telah mengkoordinir penyandang disabilitas di Sedayu yang merupakan anggota kelompok "PINILIH" untuk berpartisipasi dalam kegiatan Program Kemitraan Masyarakat ini.

\section{Daftar Pustaka}

https://www.google.com/search?client=firefox-b-d\&q=Kecamatan+Sedayu （diunduh

Oktober 2019)

Republik Indonesia. 2011. Undang-Undang Nomor 19 tahun 2011 tentang Pengesahan Convention on the Rights of Persons with Disabilities (Konvensi mengenai Hak-Hak 
Penyandang Disabilitas). Lembaran Negara Republik Indonesia Tahun 2011 Nomor 107. Sekretariat Negara. Jakarta.

Republik Indonesia. 2016. Undang-undang No 8 Tahun 2016 tentang Penyandang Disabilitas (Lembaran Negara Republik Indonesia Tahun 2016 Nomor 69.

Republik Indonesia. 2012. Peraturan Daerah Provinsi Daerah istimewa Yogyakarta Nomor 4 Tahun 2012 tentang Perlindungan dan Pemenuhan Hak-Hak Penyandang Disabilitas. Lembaran Daerah Provinsi Daerah Istimewa Yogyakarta Tahun 2012 Nomor 4. Sekretariat Daerah Provinsi Daerah Istimewa Yogyakarta. Yogyakarta

Republik Indonesia. 2015. Peraturan Daerah Provinsi Kebupaten Bantul Nomor 11 Tahun 2015 tentang Pemenuhan Hak-Hak Penyandang Disabilitas. Lembaran Daerah Kabupaten Bantul Tahun 2015 Nomor 53. Sekretariat Daerah Kabupaten Bantul Yogyakarta

Surwanti., Arni. 2018. Economic Empowerment Through Entrepreneurship Based On Local Regulation Of Protection And Fulfillment The Rights Of Persons Of Disabilities In Yogyakarta Province. Working Paper.

World Health Organization. 2010. CBR guidelines Introductory booklet. WHO Library Cataloguing-in-Publication Data. ISBN 9789241548052

Yeo, Rebecca \& Moore, Karen, 2003. "Including Disabled People in Poverty Reduction Work: "Nothing About Us, Without Us"," World Development, Elsevier, vol. 31(3), pages 571590, March.

Laporan Akhir - Memetakan Penyandang Disabilitas (PD) di Pasar Tenaga Kerja Indonesia; /Organisasi Perburuhan Internasional, Kantor Jakarta; ILO, 2017 